\title{
Pengaruh Berbagai Aditif terhadap Kandungan Serat Kasar dan Mineral Silase Kulit Pisang Kepok
}

\section{The effect of various additives on crude fiber and mineral content of kepok banana peels silage}

\author{
Hieronymus Yohanes Chrysostomus ${ }^{1)}$, Tri Anggarini Yuniwati Foenay ${ }^{2)}$, Theresia Nur Indah \\ Koni $^{3)^{*}}$ \\ ${ }^{1)}$ Program Studi Budidaya Ternak, Jurusan Peternakan, Fakultas Peternakan Universitas Papua \\ Jl. Gunung Salju, Amban, Manokwari 98314, Papua Barat. Indonesia \\ ${ }^{2)}$ Program Studi Produksi Ternak, Jurusan Peternakan, Politeknik Pertanian Negeri Kupang \\ ${ }^{3)}$ Program Studi Teknologi Pakan Ternak, Jurusan Peternakan, Politeknik Pertanian Negeri Kupang, \\ Jl. Prof. Dr. Herman Yohanis, Lasiana, Kupang 85011, NTT. Indonesia
}

\author{
Article history \\ Received: Mar 3, 2020; \\ Accepted: Jul 27, 2020 \\ * Corresponding author: \\ E-mail: \\ Indahkoni@gmail.com \\ DOI: \\ 10.46549/jipvet.v10i2.100
}

\begin{abstract}
Banana peels are rarely utilized as feedstuff alternatives due to their high content of crude fiber. Crude fiber can be reduced by biological treatment, specifically by making silage. One of the factors that influence the quality of silage is additives in the form of soluble carbohydrates. The purpose of this study was to examine crude fiber, calcium, and phosphorus banana peels silage by adding different additives. The silage of banana peel in this study used soluble carbohydrates such as rice bran, tapioca starch, and palm syrup, followed with a 21 days fermentation. This study was conducted with four treatments and five replications. The treatments were: $\mathrm{P} 0=$ banana peels without additives, $\mathrm{P} 1=$ banana peels $+5 \%$ rice bran, $\mathrm{P} 2=$ banana peels $+5 \%$ tapioca starch, $\mathrm{P} 3=$ banana peels $+5 \%$ palm syrup. Parameters measured in this study were the content of crude fiber, $\mathrm{Ca}$, and P. Data were analyzed by analysis of variance and followed by Duncan's multiple range test. The results showed that the inclusion of rice bran, tapioca starch, and palm syrup by $5 \%$ reduce the crude fiber amount while also increase calcium and phosphorus levels in banana peels. The inclusion of tapioca starch as an additive by $5 \%$ had the highest reduction of crude fiber. The highest increase in calcium and phosphorus levels were obtained by adding $5 \%$ rice bran as a silage additive. The conclusion is the inclusion of soluble carbohydrates as additives not only reduce crude fiber content but also increase mineral content in banana peels.
\end{abstract}

Keywords: Banana peels; Crude fiber; Calcium; Phosporus

\section{Abstrak}

Kulit pisang jarang dimanfaatkan sebagai bahan pakan alternatif, karena kadar serat kasar yang tinggi. Serat kasar dapat dikurangi dengan proses pengolahan biologi yaitu dengan pembuatan silase. Salah satu faktor yang mempengaruhi kualitas silase adalah aditif silase seperti karbohidrat mudah larut. Tujuan penelitian ini adalah untuk mengkaji kadar serat kasar, kalsium, dan fosfor kulit pisang yang ditambahkan aditif yang berbeda. Pembuatan silase kulit pisang dalam penelitian ini menggunakan beberapa karbohidrat mudah larut seperti dedak padi, tepung tapioka dan gula air dan difermentasi selama 21 hari. Penelitian ini dilakukan dengan 4 perlakuan dan 5 ulangan. Perlakuannya adalah: $\mathrm{P}_{0}=$ silase kulit pisang tanpa aditif, $\mathrm{P}_{1}=$ kulit pisang $+5 \%$ dedak padi, $\mathrm{P}_{2}=$ kulit pisang $+5 \%$ tapioka, $\mathrm{P}_{3}=$ kulit pisang $+5 \%$ gula air. Parameter yang diukur meliputi kandungan serat kasar, Ca dan P. Data dianalisis anova dan dilanjutkan dengan uji DMRT. Hasil penelitian menunjukkan bahwa penggunaan dedak 
padi, tapioka dan gula air sebanyak 5\% menurunkan serat kasar, dan meningkatkan kadar kalsium dan fosfor kulit pisang. Penurunan serat kasar tertinggi tertinggi pada penggunaan tapioka sebagai aditif dan mineral kalsium dan fosfor tertinggi pada penggunaan 5\% dedak padi sebagai aditif silase. Disimpulkan bahwa penggunaan karbohidrat mudah larut sebagai aditif mampu menurunkan kadar serat kasar dan meningkatkan kandungan mineral pada kulit pisang.

Kata kunci: Kulit pisang; Serat kasar; Kalsium; Fosfor

\section{PENDAHULUAN}

Kulit pisang merupakan salah satu limbah pertanian yang dapat dimanfaatkan untuk pakan ternak, karena mengandung gizi yang cukup dan cukup banyak tersedia. Wadhwa dan Bakshi (2013) menyatakan bahwa kulit pisang mengandung protein kasar mencapai 8\%, lemak kasar 6,2\%; Koni et al. (2013) kulit pisang mengandung lemak kasar 2,52\%, serat kasar 18,71\%; dan Fitroh et al. (2018) menyatakan kandungan $\mathrm{Ca} 0,27 \%$ dan fosfor $0,26 \%$. Berat kulit pisang kepok sekitar 25 40\% dari berat buah pisang (Koni et al., 2013; Wadhwa et al., 2015). Kulit pisang kepok dapat dimanfaatkan $7,5 \%$ dalam pakan broiler sedangkan kulit pisang yang difermentasi dengan Rhyzopus oligosporus dapat digunakan hingga $10 \%$ dalam ransum broiler (Koni et al., 2013); 20\% (Widjastuti dan Hernawan, 2012).

Serat kasar yang tinggi merupakan faktor pembatas pemanfaatannya dalam pakan broiler, karena itu maka perlu diperbaiki nilai nutrisinya sebelum dimanfaatkan sebagai pakan. Salah satu cara pengolahan bahan pakan yaitu pengolahan biologis atau fermentasi (Purwati dan Windyasmara, 2019). Prinsip penerapan fermentasi adalah memaksimalkan kerja mikroorganisme yang mampu mengubah komponen bahan pakan seperti menurunkan kadar serat kasar (Mandey et al., 2015); mengurangi zat anti-nutrisi dalam bahan pakan (Koni et al., 2010). Salah satu teknologi fermentasi yang biasa diterapkan pada pengolahan pakan adalah pembuatan silase. Silase merupakan hasil fermentasi dalam kondisi anaerob yang melibatkan kerja bakteri asam laktat (Handayani et al., 2018).

Proses fermentasi dalam pembuatan silase memerlukan aditif seperti sumber karbohidrat yang mudah larut (Wilkinson et al., 1976). Penambahan aditif pada fermentasi menyediakan karbohidrat mudah larut untuk dimanfaatkan oleh mikroorganisme sebagai sumber energi (Anas dan Syahrir, 2017; Handayani et al., 2018), selain itu penambahan aditif dapat mempercepat penurunan $\mathrm{pH}$ sehingga membatasi pemecahan protein dan menghambat pertumbuhan mikroorganisme aerobik merugikan (Nurmi et al., 2018). Penambahan sumber karbohidrat yang mudah dicerna seperti dedak halus, tepung tapioka, dan gula air dapat meningkatkan kualitas silase.

Dedak padi merupakan limbah dalam proses penggilingan gabah dan penyosohan beras (Astawan dan Febrinda, 2010). Wibawa et al. (2015) menyatakan bahwa dedak padi mengandung bahan organik $89,95 \%$, protein kasar 10,93\%, serat kasar 15,07\%; karbohidrat $34-62 \%$, fosfor 1100-2500 mg, dan kalsium 30$120 \mathrm{mg}$ (Astawan dan Febrinda, 2010). Penambahan dedak padi pada pembuatan silase menghasilkan tekstur silase yang baik (Kojo et al., 2015)

Gula air merupakan hasil perebusan nira lontar berbentuk cairan yang sangat kental dan lengket berwarna coklat kehitaman (Naiola, 2008). Utomo et al. (2016) melaporkan bahwa kandungan ekstrak tanpa nitrogen (ETN) gula air adalah $98,3 \%$. Penggunaan $8 \%$ gula air pada pembuatan silase sorgum.

Tepung tapioka merupakan bahan baku lokal yang berlimpah, mudah diolah dan harganya relatif murah. Selain memiliki kandungan karbohidrat yang cukup tinggi tepung tapioka mengandung amilosa sebesar $17 \%$ dan amilopektin 83\% (Sari et al., 2016). Selain itu, tapioka juga mengandung 6,4\% protein kasar, 3,6\% serat kasar, 2,9\% lemak kasar, dan 85,5\% karbohidrat (Oboh dan Elusiyan, 2007). Simanihuruk dan Sirait (2017) menyatakan bahwa penggunaan silase ampas sagu yang ditambahkan 10\% tapioka 
dapat meningkatkan pertambahan bobot badan ternak kambing. Komponen utama dari tepung tapioka adalah pati, yaitu $73,3-84,9 \%$, yang terdiri dari amilosa sebanyak $17 \%$ dan amilopektin $83 \%$. Selain itu, tapioka juga mengandung 0,08-1,54\% lemak kasar, 0,03$0,60 \%$ protein kasar dan $0,02-0,33 \%$ abu.

Penelitian ini bertujuan untuk mengetahui pengaruh penggunaan beberapa jenis karbohidrat mudah larut terhadap kadar serat kasar, kalsium, dan fosfor kulit pisang. Diharapkan dengan pembuatan silase menggunakan beberapa karbohidrat mudah larut dapat menurunkan serat kasar dan meningkatkan kandungan mineral kulit pisang sehingga lebih bermanfaat bagi ternak.

\section{MATERI DAN METODE}

\section{MATERI}

Bahan yang digunakan dalam penelitian ini adalah kulit pisang kepok yang diperoleh dari tempat pengolahan pisang, gula air, dedak padi, dan tepung tapioka, air bersih untuk mencuci kulit pisang. Alat yang digunakan seperti silo dari stoples plastik kapasitas $1 \mathrm{~kg}$, pisau untuk mengiris kulit pisang,talenan, timbangan elektrik merk Nagata berkapasitas $3 \mathrm{~kg}$ dengan kepekaan 0,2 gram serta alat lainnya untuk analisis kandungan serat kasar, kalsium, dan fosfor.

\section{PEMBUATAN SILASE}

Proses pembuatan silase kulit pisang berdasarkan petunjuk Larangahen et al. (2017) yaitu: kulit pisang yang dipilih diambil dari tempat pengolahan pisang. Kulit pisang dicuci dengan menggunakan air bersih, kemudian ditiriskan, dilanjutkan dengan pemotongan, kulit pisang dipotong $\pm 3 \mathrm{~cm}$, dan dibiarkan layu hingga 4 jam. Penambahan dengan aditif sesuai dengan perlakuan, kemudian kulit pisang dimasukan dalam silo dan dipadatkan, silo ditutup hingga rapat dan diinkubasi pada suhu ruang selama 21 hari. Setelah 21 hari dilakukan pemanenan silase, kemudian dikeringkan dalam oven $60^{\circ} \mathrm{C}$, dihaluskan dan dinalisis kandungan serat kasar, kalsium, dan fosfor.

\section{ANALISIS LABORATORIUM}

Analisis kandungan serat kasar, kalsium dan fosfor merujuk pada AOAC (2005) di mana kandungan serat kasar dengan metode ekstraksi dalam larutan asam dan basa (metode 978.10), kalsium dengan metode AAS (Metode 942.05) dan fosfor menggunakan spektrofotometri (metode 965.17).

\section{RANCANGAN PENELITIAN}

Penelitian ini menggunakan Rancangan Acak Lengkap (RAL) dengan 4 perlakuan dan 5 ulangan, adapun perlakuannya adalah:

$$
\begin{aligned}
& \mathrm{P} 1=\text { silase kulit pisang tanpa aditif } \\
& \mathrm{P} 2=\text { kulit pisang }+5 \% \text { dedak padi } \\
& \mathrm{P} 3=\text { kulit pisang }+5 \% \text { tapioka } \\
& \mathrm{P} 4=\text { kulit pisang }+5 \% \text { gula air }
\end{aligned}
$$

\section{PARAMETER PENELITIAN}

Parameter dalam penelitian ini adalah kandungan serat kasar, kalsium, dan fosfor silase kulit pisang.

\section{ANALISIS DATA}

Data kandungan serat kasar, kalsium dan fosfor dianalisis menggunakan analisis ANOVA (Analysis of Variance) dan dilanjutkan dengan DMRT (Gasperz, 2006).

\section{HASIL DAN PEMBAHASAN}

Kulit pisang mempunyai berat $25-40 \%$ dari berat buah pisang tergantung pada tingkat kematangannya, semakin matang maka berat kulit pisang semakin berkurang (Koni, 2013). Pada tahun 2017 produksi pisang di NTT sebanyak 92988,4 ton (Badan Pusat Statistik, 2018) sehigga produksi kulit pisang berkisar 23.247,1-37.195,36 ton. Pengaruh penggunaan karbohidrat yang berbeda pada pembuatan silase kulit pisang ditampilkan pada Tabel 1 .

\section{KADAR SERAT KASAR SILASE KULIT PISANG}

Perbedaan aditif yang digunakan dalam pembuatan silase menurunkan kadar serat kasar kulit pisang $(\mathrm{P}<0,05)$. Penggunaan silase aditif $\left(\mathrm{P}_{1}, \mathrm{P}_{2}\right.$, dan $\left.\mathrm{P}_{3}\right)$ menurunkan kadar serat kasar kulit masing-masing 26,04, 8,71, dan $14,69 \%$ lebih rendah daripada tanpa pemberian aditif $\left(\mathrm{P}_{0}\right)$. Tingginya penurunan serat kasar pada silase yang menggunakan aditif ini karena kebutuhan energi mikroorganisme terpenuhi sehingga meningkatkan kinerja mikroorganisme untuk menurunkan serat kasar substrat dalam hal ini kulit pisang. Turunnya kadar serat kasar ini disebabkan karena aktivitas selulolitik mikro organisme pada proses fermentasi. Wajizah et al. (2015) 
menyatakan bahwa penurunan serat kasar pada silase pelepah sawit yang menggunakan karbohidrat mudah larut 6,61-9,64\%.

Kulit pisang tanpa fermentasi memiliki kadar serat kasar 18,71\% (Koni, 2013) lebih tinggi daripada kulit pisang fermentasi baik yang ditambahkan dengan aditif maupun tanpa penambahan aditif $(10,63-14,37 \%)$. Proses fermentasi (silase) menyebabkan penurunan serat kasar. Silase dengan tambahan aditif maka jumlah kebutuhan energi untuk pertumbuhan mikroorganisme tercukupi sehingga populasi mikroorganime meningkat dan aktivitas mikroba pendegradasi serat pun meningkat.

Table 1. Pengaruh penambahan berbagai karbohidrat mudah larut terhadap kadar serat kasar, kalsium dan fosfor kulit pisang

\begin{tabular}{|c|c|c|c|c|}
\hline \multirow{2}{*}{ Kadar nutrien (\%) } & \multicolumn{4}{|c|}{ Perlakuan } \\
\hline & $\mathbf{P}_{0}$ & $\mathbf{P}_{1}$ & $\mathbf{P}_{2}$ & $\mathbf{P}_{\mathbf{3}}$ \\
\hline Serat kasar & $14,37 \pm 0,95^{a}$ & $10,64 \pm 0,55^{\mathrm{c}}$ & $13,12 \pm 0,42^{b}$ & $12,26 \pm 0,83^{b}$ \\
\hline Calsium & $0,69 \pm 0,05^{b}$ & $0,78 \pm 0,06^{\mathrm{a}}$ & $0,79 \pm 0,04^{\mathrm{a}}$ & $0,70 \pm 0,07^{\mathrm{b}}$ \\
\hline Fosfor & $0,17 \pm 0,04^{c}$ & $0,24 \pm 0,01^{b}$ & $0,49 \pm 0,08^{\mathrm{a}}$ & $0,20 \pm 0,03^{b c}$ \\
\hline
\end{tabular}

Kadar serat kasar pada perlakuan tanpa aditif $\left(\mathrm{P}_{0}\right)$ nyata lebih tinggi $(\mathrm{P}<0,05)$ daripada perlakuan P1, P2 dan P3. Kadar serat kasar pada penggunaan aditif tepung tapioka $(\mathrm{P} 1)$ nyata $(\mathrm{P}<0,05)$ lebih rendah daripada $\mathrm{P}_{2}$ dan $\mathrm{P}_{3}$. Sedangkan pada silase yang menggunakan aditif dedak padi $\left(\mathrm{P}_{2}\right)$ dan gula air $\left(\mathrm{P}_{3}\right)$ tidak berbeda nyata $(\mathrm{P}>0,05)$. Hal ini disebabkan karena kandungan karbohidrat yang tinggi pada tepung tapioka. Astuti et al. (2017) menyatakan bahwa tepung tapioka yang merupakan umbi ketela pohon yang sudah dikeringkan dan dihaluskan mempunyai kandungan karbohidrat sekitar 86,9\%. Kandungan ETN pada dedak halus $48,7 \%$ (Utomo et al., 2016). Riswandi (2014) mengemukakan bahwa pembuatan silase eceng gondok yang ditambahkan 5\% tepung ubi kayu menghasilkan kadar serat kasar terendah.

\section{KADAR KALSIUM SILASE KULIT PISANG}

Kalsium merupakan makro mineral yang berhubungan langsung dengan perkembangan dan pemeliharaan sistem skeleton serta berpartisipasi dalam berbagai proses fisiologis tubuh organisme (Kwiatkowska et al., 2017). Perbedaan aditif yang digunakan dalam pembuatan silase meningkatkan kadar kalsium kulit pisang $(\mathrm{P}<0,05)$. Peningkatan mineral ini disebabkan kareana sumbangan mineral dari mikroorganisme pada pembuatan silase. Basri et al. (2019) menyatakan bahwa peningkatan kalsium selama fermentasi disebabkan kandungan kalsium yang berasal dari masa sel mikroba yang tumbuh dan berkembang biak pada media selama fermentasi. Bila dibandingkan dengan kadar kalsium pada kulit pisang tanpa fermentasi yaitu sebesar $0,27 \%$ (Fitroh et al., 2018), maka proses pembuatan silase ini meningkatkan kadar kalsium menjadi 0,68-0,79\%.

Penggunaan aditif tepung tapioka dan dedak padi mempunyai kadar kalsium yang lebih tinggi masing-masing $(13,20 \%$ dan $14,80 \%)$ daripada silase tanpa aditif $\left(\mathrm{P}_{0}\right)$. Sedangkan yang menggunakan aditif gula air tidak berbeda nyata $(\mathrm{P}>0,05)$ dengan silase tanpa aditif $\left(\mathrm{P}_{0}\right)$. Perbedaan kadar kalsium ini disebabkan karena sumbangan kadar kalsium dari aditif yang digunakan. Parakkasi (1983) menyatakan bahwa kandungan kalsium pada dedak padi sebesar $0,1 \%$ dan tepung tapioka 0,15\%. Basri et al. (2019) menyatakan bahwa komposisi bahan yang dibuatkan silase akan mempengaruhi kadar kalsium silase yang dihasilkan.

Proses fermentasi dapat meningkatkan kadar kalsium kulit pisang yang difermentasi dengan ragi tempe meningkat sebesar $5,71 \%$ (Koni, 2013). Kulit pisang yang difermentasi dengan ragi tape memiliki kandungan kalsium sebesar 0,5-0,8\% (Koni et al., 2019); yang difermentasi dengan Neurospora crassa 
memiliki kadar kalsium 0,89\% (Dorisandi et al., 2017).

\section{KADAR FOSFOR SILASE KULIT PISANG}

Fosfor (P) merupakan mineral kedua terbanyak dalam tubuh dengan distribusi dalam jaringan yang menyerupai distribusi Ca. Fosfor berperan penting dalam proses mineralisasi tulang. Penggunaan aditif pada pembuatan silase kulit pisang menyebabkan peningkatan kadar fosfor $(\mathrm{P}<0,05)$. Kadar fosfor tertinggi $(0,49 \%)$ ada pada aditif yang menggunakan dedak padi. Hal ini disebabkan karena kandungan fosfor dari aditif memberikan sumbangan pada kadar fosfor silase yang dihasilkan. Kandungan fosfor dedak padi 1,7\% dan tapioka 0,08\% (Parakkasi, 1983). Selain itu proses fermentasi dapat mendegradasi fitat yang mengikat fosfor pada bahan pakan seperti pada dedak padi. Hasil penelitian ini sesuai dengan pendapat Siahaan et al. (2015) menyatakan bahwa terjadi peningkatan fosfor karena penurunan asam fitat pada kacang sesame yaitu sebelum fermentasi 31,59 (mg/g) menjadi $18,13(\mathrm{mg} / \mathrm{g})$ setelah difermentasi secara natural selama 96 jam. Kadar fosfor pada kulit pisang yang difermentasi dengan ragi tape yaitu $0,12,0,16,0,18$ dan $0,26 \%$ pada penggunaan $0,1,5,3$, dan $4,5 \%$ ragi tape (Koni et al., 2019).

\section{KESIMPULAN}

Berdasarkan hasil dan pembahasan maka dapat disimpulkan bahwa penggunaan jenis karbohidrat mudah larut yang berbeda menghasilkan silase kulit pisang yang mempunyai kadar serat kasar yang lebih rendah, dan kadar kalsium, kadar fosfor yang lebih tinggi daripada silase tanpa karbohidrat mudah larut. Penggunaan tapioka 5\% menghasilkan kadar serat kasar terendah $(10,64 \%)$ dan penggunaan $5 \%$ dedak padi menghasilkan kadar kalsium tertinggi $(0,791 \%)$ dan fosfor tertinggi $(0,486 \%)$.

\section{DAFTAR PUSTAKA}

Anas M. A. dan Syahrir. 2017. Pengaruh penggunaan jenis aditif sebagai sumber karbohidrat terhadap komposisi kimia silase rumput mulato. Jurnal Agrisains. 18(1): 13-22.
AOAC. 2005. Official Methods of Analysis of the Association of Official Analytical Chemists (18th ed.). Washington, DC

Astawan M. dan Febrinda E. 2010. Potensi dedak dan bekatul beras sebagai ingredient pangan dan produk pangan fungsional. Pangan.19(1): 14-21.

Astuti T., Rofiq M. N. dan Nurhaita. 2017. Evaluasi kandungan bahan kering, bahan organik dan protein kasar pelepah sawit fermentasi dengan penambahan sumber karbohidrat. Jurnal Peternakan. 14(2): 4247.

Badan Pusat Statistik. 2018. Statistik Pertanian. Kupang: Badan Pusat Statistik Provinsi NTT.

https://ntt.bps.go.id/dynamictable/2018/02 /05/566/produksi-pisang-menurutkabupaten-kota-di-provinsi-nusatenggara-timur-2011-2017.

Basri, Nurhaedah, dan Fitriani. 2019. Kandungan kalsium $(\mathrm{Ca})$ dan fospor $(\mathrm{P})$ silase kombinasi jerami padi dan daun lamtoro sebagai pakan ternak ruminansia. Jurnal Bionature. 20(1): 21-26.

Dorisandi M., Saputro L., Jatmiko S. H. dan Fenita Y. 2017. Pengaruh pemberian fermentasi tepung kulit pisang jantan dengan menggunakan Neurospora crassa terhadap deposisi lemak ayam broiler. Jurnal Sain Peternakan Indonesia. 12(3): 325-334.

Fitroh B. A., Wihandoyo and Supadmo. 2018. The use 3 of banana peel meal (Musa paradisiaca) as substitution of corn in the diets on performance and carcass production of hybrid ducks. Buletin Peternakan. 42(3): 222-231.

Gasperz V. 2006. Teknik Analisa Dalam Penelitian Percobaan (Edisi III). Tarsito. Bandung:

Handayani S., Haraha A. E. dan Saleh E. 2018. Kandungan fraksi serat silase kulit pisang kepok (Musa Paradisiaca) dengan penambahan level dedak dan lama pemeraman yang berbeda. Jurnal Peternakan. 15(1): 1-8.

Kojo R. M., Rustandi, Tulung Y. R. L. dan Malalantang S. 2015. Pengaruh penambahan dedak padi dan tepung jagung terhadap kualitas fisik silase rumput gajah (Pennisetum purpureum cv.hawaii). Jurnal 
Zootek. 35(1): 21-29.

Koni T. N. I. 2013. Effect of fermented banana peel on broiler carcass. Jurnal Ilmu Ternak Dan Veteriner. 18(2): 153-157.

Koni T. N. I., Bale-Therik J. and Kale P. R. 2013. Utilizing of fermented banana peels by Rhyzopus oligosporus in ration on growth of broiler. Jurnal Veteriner. 14(3):365-370.

Koni T. N. I., Foenay T. A. Y. and Asrul. 2019. The nutrient value of banana peel fermented by tape yeast as poultry feedstuff. Jurnal Ilmu-Ilmu Peternakan. 29(3): 211-217.

Koni T. N. I., Paga A. dan Jehemat A. 2010. Kandungan protein kasar dan tanin biji asam yang difermentasi dengan Rhyzopus Oligosporus. Partner. 20(2): 127-132.

Kwiatkowska K, Winiarska-mieczan A. and Kwiecien M. 2017. Feed additives regulating calcium homeostasis in the bones of poultry - a review. Annals of Animal Science. 17(2): 303-316.

Larangahen A., Bagau B., Imbar M. R. dan Liwe H. 2017. Pengaruh penambahan molases terhadap kualitas fisik dan kimia silase kulit pisang sepatu (Mussa paradisiaca formatypica). Jurnal Zootek. 37(1): 156-166.

Mandey J. S., Leke J. R., Kaunang W. B. and Kowel Y. H. S. 2015. Carcass yield of broiler chickens fed banana (Musa paradisiaca) leaves fermented with Trichoderma viride. Journal of the Indonesian Tropical Animal Agriculture. 40(4):229-233.

Naiola E. 2008. Mikrobia amilolitik pada nira dan laru dari pulau Timor, Nusa Tenggara Timur. Biodiversitas. 9(3):165-168.

Nurmi A., Santi M. A., Harahap N. and Harahap M. 2018. Percentage of carcass and mortality of broiler and native chicken fed with unfermented and fermented arenga waste. Jurnal Ilmiah Peternakan Terpadu. 6(3):134-139.

Oboh G. and Elusiyan C. A. 2007. Changes in the nutrient and anti-nutrient content of micro-fungi fermented cassava flour produced from low- and medium-cyanide variety of cassava tubers. African Journal of Biotechnology. 6(18):2150-2157.

Parakkasi A. 1983. Ilmu Gizi dan Makanan
Ternak Monogastrik. Angkasa. Bandung.

Purwati C. S. dan Windyasmara L. 2019. Fermentasi biji kecipir (Psophocarpus tetragonolobus) oleh jamur Trichoderma viride terhadap warna, tekstur, dan serat kasar. Jurnal Ilmu Peternakan Dan Veteriner Tropis (Journal of Tropical Animal and Veterinary Science). 9(1): 1-5.

Riswandi. 2014. Kualitas silase eceng gondok (Eichhornia crassipes) dengan penambahan dedak halus dan ubi kayu. Jurnal Peternakan Sriwijaya. 3(1): 1-6.

Sari I. Y., Santoso L. dan Suparmono. 2016. Kajian pengaruh penambahan tepung tapioka sebagai Binder dalam pakan buatan terhadap pertumbuhan ikan nila gift (Oreochromis sp.). E-Jurnal Rekayasa Dan Teknologi Budidaya Perairan. 5(1): 537-546.

Siahaan N., Sunarti D. dan Yunianto V. 2015. Pengaruh penggunaan kulit pisang biokonversi dalam ransum terhadap penyerapan kalsium serta pertumbuhan tulang ayam broiler. Buletin Nutrisi Dan Makanan Ternak. 13(1): 14-18.

Simanihuruk K., dan Sirait J. 2017. Silase Ampas sagu menggunakan tiga bahan aditif sebagai pakan basal kambing boerka fase pertumbuhan. Prosiding Seminar Nasional Teknologi Peternakan dan Veteriner.

Utomo R., Noviandi C. T., Astuti A., Umami N., Kale-Lado L. J. M. C., Pratama A. B. dan Sugiyanto N. 2016. Pengaruh penggunaan aditif pada kualitas silase hijauan Sorghum vulgare. Simposium Nasional Penelitian dan Pengembangan Peternakan Tropik Fakultas Peternakan Universitas Gadjah Mada. Yogyakarta.

Wadhwa M. and Bakshi P. S. 2013. Utilization of fruit and vegetable wastes as livestock feed and as substrates for generation of other value added products. Journal of Neurochemistry. 105(2): 369-379.

Wadhwa M., Bakshi M. P. and Makkar H. P. 2015. Waste to worth: fruit wastes and byproducts as animal feed. CAB Reviews. 10(31): 1-10.

Wajizah S., Samadi S., Usman Y. dan Mariana E. 2015. Evaluasi nilai nutrisi dan kecernaan in vitro pelepah kelapa sawit (oil palm fronds) yang difermentasi 
menggunakan Aspergillus niger dengan penambahan sumber karbohidrat yang berbeda. Jurnal Agripet. 15(1):13-19.

Wibawa A. A. P., Wirawan I. W. dan Partama I. B. G. 2015. Peningkatan nilai nutrisi dedak padi sebagai pakan itik melalui biofermentasi dengan khamir. Majalah Ilmiah Peternakan. 18(1):11-16.
Widjastuti T. and Hernawan E. 2012. Utilizing of banana peel (Musa sapientum) in the ration and its influence on final body weight, percentage of carcass and abdominal fat on broiler. Lucrări Ştiinţifice - Seria Zootehnie. 57: 104-109.

Wilkinson J. M., Wilson R. F. dan Barry T. 1976. Factors affecting the nutritive value of silage. Outlook on Agriculture. 9(1): 38. 